УДК 339.14:663.64

DOI: $10.15673 /$ fie.v12i2.1736

\author{
Файвішенко Д.С. \\ кандидат економічних наук, доцент, \\ кафедра журналістики та реклами \\ Київський національний торговельно-економічний університет \\ вул. Кіото, 19, м. Київ, Україна, 02156 \\ E-mail: fayvishenko.ds@gmail.com \\ ORCID ID: 0000-0001-7880-9801
}

\title{
АНАЛІЗ ТЕНДЕНЦІЙ РОЗВИТКУ РЕГІОНАЛЬНИХ РИНКІВ МІНЕРАЛЬНОÏ ВОДИ УКРАЇНИ
}

Сьогодні в умовах трансформації та динамічного розвитку нових сфер економіки, враховуючи позитивну макроекономічну динаміку та соціально-екологічний вплив фракторів (загострення екологічної ситуації, підсилення інтересу до укріплення культурних традицій, зміни споживчих стереотипів), розвиток ринку мінеральної води займає провідні позиції, де домінантною тенденцією $€$ аналіз регіонального ринку. У статті представлено аналіз та моніторинг стану видобутку та тенденцій розвитку регіонального ринку мінеральної води, проведена оцінка бальнеологічних запасів у областях та виокремлено провідні торгові марки. Зроблено акцент на нівелювання чинників, які негативно впливають на економічний розвиток регіону, просування та вихід на інші регіони торговельних марок із збереженням територіально-локальних тенденцій. Сформовано 3 точки зору регіональної диференціації виробничих потужностей видобуток мінеральної води в Україні, виокремлено ключові області, яким належить виробництво 50\% обсягу даної продукції: Закарпатська, Львівська, Полтавська та Івано-Франківська.

Ключові слова: аналіз ринку, бренд, регіональний ринок, мінеральна вода, торговельна марка.

This work is licensed under a Creative Commons Attribution 4.0 International License http://creativecommons.org/licenses/by/4.0/

Постановка проблеми та їі зв'язок з важливими науковими та практичними завданнями. Сьогодні в умовах трансформації та динамічного розвитку нових сфер економіки, враховуючи позитивну макроекономічну динаміку та соціально-екологічний вплив факторів (загострення екологічної ситуації, підсилення інтересу до укріплення культурних традицій, зміни споживчих стереотипів), розвиток ринку мінеральної води займає провідні позиції, де домінантною тенденцією є аналіз регіонального ринку. Питання оцінки бальнеологічних запасів у областях регіонів, підтримки та розвитку брендів з урахуванням територіально-локальних тенденцій, формування конкурентних стратегій управління торговельними марками у перспективі залишаються досить актуальними і потребують детального аналізу.

Аналіз останніх публікацій по проблемі. Аналізу питань щодо стану та розвитку ринку мінеральної води на регіональному рівні, присвячено праці відомих дослідників таких як С. Ахромкін [1], Т. Верещака [2], Н. Малишева [3], Ю. Пахтер [4], О. Стецюк [5], I. Тюха [6], О. Тур [7], В. Химинець [8] та ін.

Формулювання цілей дослідження. Аналіз та моніторинг стану, видобутку та тенденцій розвитку регіонального ринку мінеральної води, виокремлення торгових марок у регіональному зрізі, оцінка бальнеологічних запасів у областях регіонів.

Виклад основних результатів та їx обгрунтування. Водні споживчі ресурси є одними 3 найважливіших видобувних природних ресурсів України. Ефективне та раціональне використання яких забезпечує первинні потреби споживчої аудиторії, підвищує експортний потенціал країни та сприяє формуванню позитивного іміджу в цілому. Україна є однією $з$ лідируючих європейських країн 3 видобутку і реалізації мінеральних вод. На сьогодні, в Україні видобуток підземних вод з урахуванням балансових родовищ збільшився на $2 \%, 28,336$ тис. м 3 /добу і склав у 2018 році 1472,358 тис. м $^{3} /$ добу, 3 іншого боку, у 2017 році - 1444,022 тис. ${ }^{3} /$ добу [9].

У регіональному зрізі, всі області України представлено мінеральними водами різного складу. Найбільша питома вага в балансових запасах Донецькій області (53\%), Одеській $(9,69 \%)$, Запорізькій $(7,39 \%)$, Львівській $(6,60 \%)$, Полтавській області (рис. 2.).

На сьогодні, налічується 129 ділянок вод в Україні для яких характерно насиченість специфічними властивостями та компонентами, де спостерігається лікувальний ефект. Типи мінеральних вод та регіональні джерела наявності систематизовано у вигляді таблиці 1. 


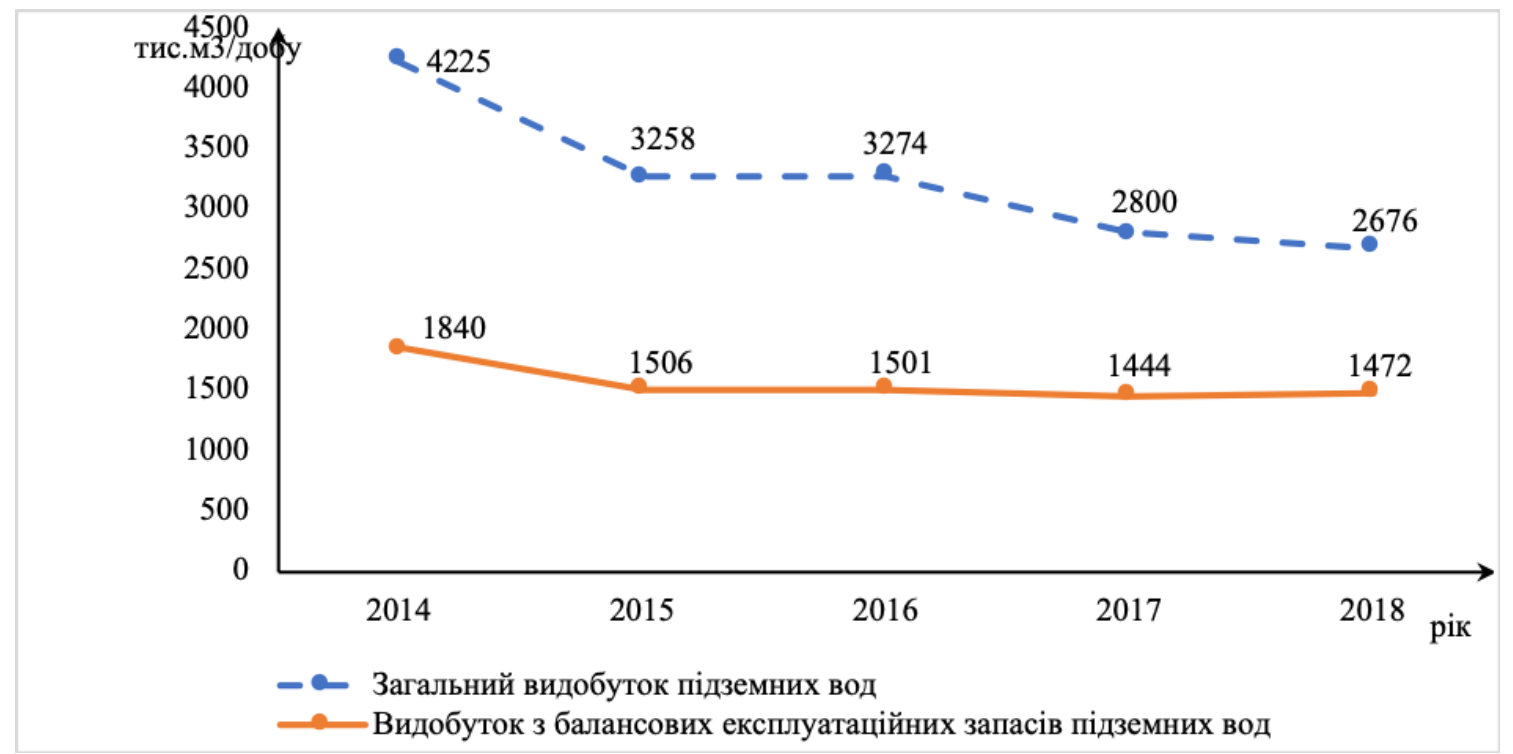

Рис.1. Загальний видобуток підземних вод з балансових запасів України станом на 01.11.2019 p. [9]

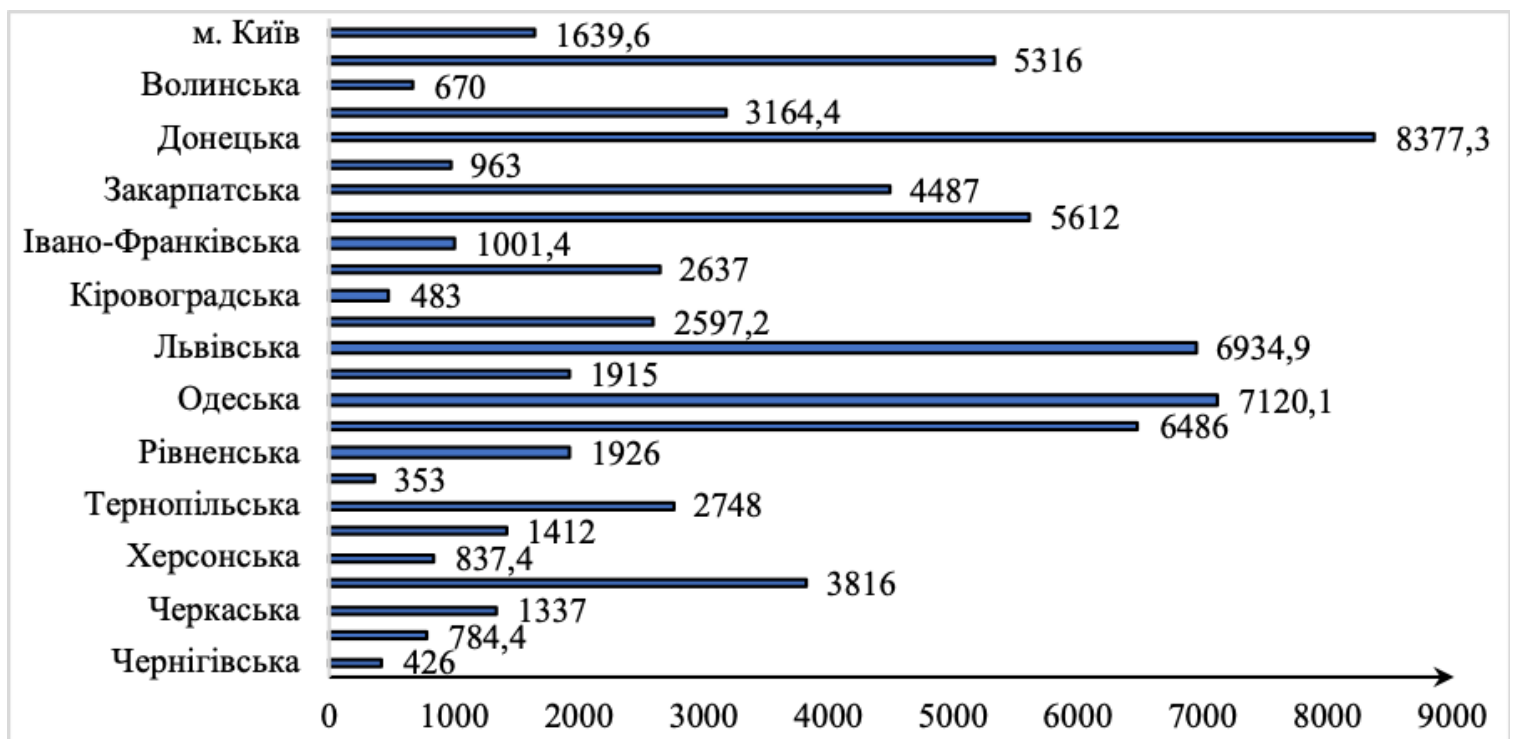

Рис. 2. Розподіл балансових експлуатаційних запасів мінеральних вод України, м³/добу станом на 01.11.2019 р. [9]

Таблиця 1

Типи мінеральних вод за регіонами [11]

\begin{tabular}{|c|c|c|}
\hline Типи мінеральних вод & $\begin{array}{l}\text { Кількість } \\
\text { ділянок }\end{array}$ & Регіон \\
\hline $\begin{array}{l}\text { Радонова } \\
\text { Без специфічних компо- } \\
\text { нентів та властивостей }\end{array}$ & 4 & Київська \\
\hline $\begin{array}{l}\text { Сульфідна } \\
\text { Підвищена концентрація } \\
\text { органічних компонентів }\end{array}$ & $\begin{array}{l}3 \\
6\end{array}$ & Львівська \\
\hline Сульфідна & 3 & Чернівецька \\
\hline $\begin{array}{l}\text { Сульфідна } \\
\text { Підвищена } \\
\text { Концентрація } \\
\text { органічних компонентів } \\
\text { Бромна }\end{array}$ & $\begin{array}{l}3 \\
3 \\
2\end{array}$ & Тернопільська \\
\hline
\end{tabular}


ISSN 2312-847X ЕКОНОМІКА ХАРЧОВОЇ ПРОМИСЛОВОСТІ Том 12, Випуск 2/2020

\begin{tabular}{|c|c|c|}
\hline & & Продовження табл. \\
\hline Типи мінеральних вод & $\begin{array}{l}\text { Кількість } \\
\text { ділянок }\end{array}$ & Регіон \\
\hline $\begin{array}{l}\text { Бромна } \\
\text { Кремниста } \\
\text { Радонова }\end{array}$ & $\begin{array}{l}4 \\
3 \\
5\end{array}$ & Дніпропетровська \\
\hline $\begin{array}{l}\text { Бромна } \\
\text { Йодно-бромна }\end{array}$ & $\begin{array}{l}3 \\
1\end{array}$ & Запорізька \\
\hline $\begin{array}{l}\text { Бромна } \\
\text { Йодно-бромна } \\
\text { Йодно-бромна борна }\end{array}$ & $\begin{array}{l}3 \\
1 \\
1 \\
\end{array}$ & Херсонська \\
\hline Йодно-бромна & 1 & Дніпропетровська \\
\hline Йодно-бромна борна & 1 & Івано-Франківська \\
\hline Залізиста Радонова & 5 & Донецька \\
\hline $\begin{array}{l}\text { Вуглекисла, Вуглекис- } \\
\text { ла борна } \\
\text { Вуглекисла } \\
\text { миш'яковиста } \\
\text { Вуглекисла йодно- } \\
\text { бромна } \\
\text { Вуглекисла залізиста } \\
\text { Вуглекисла кремниста } \\
\text { Йодно-бромна борна } \\
\text { Борна } \\
\text { Кремниста } \\
\text { Сульфідна }\end{array}$ & $\begin{array}{c}10 \\
10 \\
2 \\
2 \\
1 \\
\\
2 \\
3 \\
1 \\
2 \\
2 \\
3\end{array}$ & Закарпатська \\
\hline Кремниста & 3 & Вінницька, Харківська \\
\hline Бромна & 10 & $\begin{array}{l}\text { Луганська, Миколаївська, Одеська, Полтавська, Рівненська, Хме- } \\
\text { льницька, Волинська, }\end{array}$ \\
\hline Радонова & 23 & $\begin{array}{l}\text { Хмельницька, Вінницька, Житомирська, Київська, Кіровоградсь- } \\
\text { ка,Рівненська, Черкаська }\end{array}$ \\
\hline $\begin{array}{l}\text { Підвищена концентра- } \\
\text { ція органічних компо- } \\
\text { нентів }\end{array}$ & 10 & Вінницька, Івано-Франківська, Хмельницька \\
\hline
\end{tabular}

У Карпатському регіоні України, площею 5660,7 тис. га, що є справжнім природним досягненням країни, найбільш розповсюджені та широко використовуються вуглекислі мінеральні води: це регіон Закарпатської області: Закарпаття (Лужанська мінеральна вода), Голубинське, Келечинське, Новополянське, Шаянське, Полянське родовища; широко розповсюджені курорти Гірська Тиса, Поляна, Свалявська, Шаян. Мінеральною водою 3 підвищеною концентрацією органічних компонентів насичені Східницьке та Трускавецьке середовище Львівщини.

Мінеральні води сульфідні використовуються при застосуванні ванн, зрошенні, інгаляцій, при лікуванні серцево-судинної системи, органів опорнорухового апарату, нервової системи. В Україні відомі джерела з сульфідною мінеральною водою розташовані у регіонах Івано-Франківської області, Чернівецької, Львівської, Закарпатської областях. Особливо на курортах заходу України: Любінь Великий, Черче, Синяк, Немирів.

Мінеральні води насичені радоном розповсюджені та видобуваються у Київській області, Приазов'ї та у басейні Південного Бугу, широко використовуються як зовнішній засіб при лікуванні захворювань шкіри, органів опорно-рухового апарату та при лікуванні серцево-судинної системи. В Україні радонові джерела розташовані у місті Хмільник Хмельни- цького району, у місті Біла Церква Київської області, широко розповсюджені у Вінницькій, Черкаській, Житомирській областях.

Родовища 3 хлоридно-натрієвою мінеральною водою насиченою бромом, йодом розташовані у регіонах Карпат, Передкарпаття та Закарпаття (Берегівська курортно-рекреаційна зона), на курортах у місті Бердянськ Запорізької області [11].

Мінеральні води миш'яковисті в Україні зустрічаються локально у Закарпатській області в районі с. Кваси Рахівського району. На основі їх використання функціонує санаторій «Гірська Тиса», який має лише 2 світових аналога.

Мінеральні столові та лікувальні води залізисті (аніонові та катіонові за складом) представлено у Новоселицькому, Вінницькому, Сокирянському та Хотинському районах Чернівецької області, Донецької області (м. Слов'янськ, м. Слов'яногірськ).

Кременистими мінеральними водами багата Харківська область, де можна зустріти відомі Березівські Мінеральні Води.

Мінеральні води у складі яких спостерігається підвищена концентрація органічних складових та компонентів, лужні мінеральні води типу «Нафтуся», «Боржомі», широко представлені на території Тернопільської, Івано-Франківської, Хмельницької, Чернівецької, Львівської областях (м. Трускавець). 
На сьогодні відомі бальнеологічні курорти Сатанов, Східниця, санаторій «Збруч», «Україна» (с. Маків Дунаєвського району Хмельницької області) $є$ курортними перлинами України.

Мінеральні лікувальні води з низькою концентрацією специфічних складових та компонентів, 3 високим складом іонів та загальною мінералізацією широко застосовуються у бальнеологічних відомих курортах Полтавської області (м. Миргород), Львів- ської області (м. Моршин, м. Трускавець), Донецької області ( м. Слов'янськ) $[3,12]$.

В цілому, однією зі специфічних особливостей ринку мінеральної води $є$ те, що виробництво вод орієнтовано на сировинну складову, де значна частина загального обсягу видобувається у чотирьох областях - Закарпатська, Львівська, Полтавська та ІваноФранківська. (табл.2) [16].

Таблиця 2

Регіональний аналіз видобутку мінеральних вод станом на 01.11.2019 р.*

\begin{tabular}{|c|c|}
\hline Область & Родовище підземних мінеральних вод \\
\hline Вінницька & $\begin{array}{l}\text { Родовище: Верхівське, Матейківське, Немирівське, Новохмельницьке, Острівне, Регіна, } \\
\text { Тяжилівське, Хмельницьке, Холоневське (мінеральна вода «Подільська», «Дана», «Вер- } \\
\text { хівська Перлина», «Абсолют», «Барчанка», «Яружанка», «Шумилівська», «Караван», } \\
\text { «Регіна») }\end{array}$ \\
\hline Волиньська & $\begin{array}{l}\text { Липинське родовище, Луцьке родовище (мінеральна вода «Йоданка Павлівська», «Сте- } \\
\text { панська», «Червона калина») }\end{array}$ \\
\hline Дніпропетровська & $\begin{array}{l}\text { Родовище: Дніпропетровьске, Знаменівське, Криворізьке, Кришталеве, Новотроїцьке, } \\
\text { Самарське, Солонолиманське, Царичанське (мінеральна вода «Новотроїцька», «Цари- } \\
\text { чанська», «Знаменивська» }\end{array}$ \\
\hline Донецька & Родовище: Слов'янське (мінеральна вода «Золотий Колодязь» \\
\hline Житомирська & Родовище: Денишівське \\
\hline Закарпатська & $\begin{array}{l}\text { Родовище: Баранинське, Велятинське, Гірськотисенське, Голубинське (ділянка Голубин- } \\
\text { ська, Квітка Полонини, Луги, Маргіт), Деренівське, Драгівське, Косинське, Неліпинське, } \\
\text { Ніжнєсолотвинське, Нова Поляна (ділянка Нова Поляна 1, Поляна Квасова), Плосківсь- } \\
\text { ке, Полянське (ділянка Ведмежа, Поляна Купіль), Свалявське, Синякське, Сойминське, } \\
\text { Теплиця, Шаянське (ділянка Шаянська), (мінеральна вода «Поляна Квасова», «Поляна } \\
\text { Купель», «Лужанська», «Шаянська», «Куяльник», «Поляна Цілюща», «Поляна Срібна», } \\
\text { «Поляна Квасова», «Закарпатська Крайна», «Плосківська», «Шаянка», «Драгівська», } \\
\text { «Шаянська» }\end{array}$ \\
\hline Запорізька & $\begin{array}{l}\text { Родовище: Азов, Бердянське, Кирилівське, Лазурне, Мирненське, Молочанське, Нива } \\
\text { (мінеральна вода «Мелітопольська мінеральна вода», «Приазовская вода» }\end{array}$ \\
\hline Івано-Франківська & $\begin{array}{l}\text { Родовище: Бабухівське, Воронівське, Кліщивнянське, Ново-Мізунське, Підлютинське, } \\
\text { Пістинське, Поточищенське, Рогатинське, Семаківське, Слобідське, Старолисецьке, Те- } \\
\text { кучанське (мінеральна вода «Рогатинська», «Рогатинська джерельна», «Roksolana», «Го- } \\
\text { рянка», «Перегінська», «Довбушева Вода», «Аршиця», «Джерело Якова», «Корона Кар- } \\
\text { пат», «Пістинська Джерельна», «Voda», «Девайтіс» }\end{array}$ \\
\hline $\begin{array}{l}\text { Київська область, } \\
\text { Київ }\end{array}$ & $\begin{array}{l}\text { Родовище: Білоцерківське (ділянка Голендарня), Миронівське, Каліпсо, Оболонь, Софія } \\
\text { Київська (мінеральна вода «Слобідська», «Софія Київська», «Росяна») }\end{array}$ \\
\hline Кіровоградська & Ррдовище: Вербівське, Знаменське \\
\hline Луганська & $\begin{array}{l}\text { Родовище: Лиманське (ділянка Старобільська), Новопсковське (ділянка Південна), } \\
\text { ворозсошанське }\end{array}$ \\
\hline Львівська & $\begin{array}{l}\text { Родовище: Бережанське, Великолюбінське, Голобутівське, Дублянське, Зарічненське, } \\
\text { Краснянське, Моршинське (ділянка Джерело Моршинське, Джерело №4, Баня, Боніфа- } \\
\text { цій), Мражницьке, Немирівське, Південно-Скрутинське, Північно-Помірецьке, Підбузь- } \\
\text { ке (ділянка Сторонявська), Помірецьке, Солукське (ділянка Солукська), Стрілківське, } \\
\text { Східницьке (ділянка Горби, Гуцулка, Смереківська), Трускавецьке (ділянки: Нафтуся, } \\
\text { Липки 2, Воротище, Юзя), Шклівське, Яружно-Помірецьке ( ділянки: Яружна, Яружно- } \\
\text { Помірецька 1) (мінеральна вода: «Моршинська», «Карпатська джерельна», «Миргород- } \\
\text { ська», «Солуки», «Гірська кришталева», «Свалява», «Олеська», «Трускавецька», «Дже- } \\
\text { рело Довбуша», «Нафтуся») }\end{array}$ \\
\hline Миколаївська & Родовище: Вознесенське, Воскресенське, Кривоозерське (мінеральна вода «Кривозерсьа») \\
\hline Одеська & $\begin{array}{l}\text { Родовище: Куяльницьке, Лібра (мінеральна вода: «Куяльник», «Викторія», «Тонус Кис- } \\
\text { лород», «Жемчужина») }\end{array}$ \\
\hline Полтавська & $\begin{array}{l}\text { Родовище: Зіньківське, Майбородівське, Миргородське ( ділянка Завод «Калинка», Завод } \\
\text { МІНВОД, Миргородська Лагідна 1, Південна, Миргородська 3), Новосанжарське 2, Хо- } \\
\text { рольське 3, Шишацьке (мінеральні води: «Buvette», «Гоголівська», «Сорочинська», } \\
\text { «Аляска») }\end{array}$ \\
\hline
\end{tabular}


Продовження табл. 2

\begin{tabular}{|l|l|}
\hline \multicolumn{1}{|c|}{ Область } & \multicolumn{1}{c|}{ Родовище підземних мінеральних вод } \\
\hline Рівненська & $\begin{array}{l}\text { Родовище: Жобринське (ділянка Водограйна, Жобринська 1), Корецьке 2, Маломидське, } \\
\text { Острозьке }\end{array}$ \\
\hline Сумська & Родовище: Іволжанське, Михайлівське, Токарівсько-Бережківське \\
\hline Тернопільська & $\begin{array}{l}\text { Родовище: Добра Вода, Кинахівське, Конопківське (ділянка Конопківська 1), Надзбру- } \\
\text { чанське, Суходільське }\end{array}$ \\
\hline Харківська & Родовище: Березівське, Зміївське, Шатилівське \\
\hline Херсонська & Родовище: Шатилівське, Гаряче Джерело, Каховка, Любимівське \\
\hline Хмельницька & $\begin{array}{l}\text { Родовище: Волочинське, Збручанське ( ділянка Збручинське 1, Східна), Зінківське, Кра- } \\
\text { силівське, Маківське, Мукшинське }\end{array}$ \\
\hline Черкаська & Родовище: Мошногірське (ділянка Мошногір’я), Тальнівське, \\
\hline Чернівецька & Родовище: Брусницьке (ділянка Брусницька 1), Валякузминське, Хрещатицьке \\
\hline Чернігівська & Родовище: Менське \\
\hline
\end{tabular}

*сформовано автором на основі [16]

За даними Державної служби геології та надр України, серед областей Карпатського регіону України Львівська область має найбільші запаси мінеральних вод (понад $5000 \mathrm{~m}^{3} /$ добу) і належить до групи областей 3 найбільшими балансовими експлуатаційними запасами мінеральних вод (разом із Вінницькою, Запорізькою, Одеською, Донецькою областями) [12].

На сьогодні, Карпатський регіон займає провідні позиції на українському ринку мінеральних вод, де зосереджені основні виробники відомих брендів мінеральних вод, які мають попит у споживчої аудиторії. Зокрема, частка Карпатського регіону України в загальному виробництві безалкогольних напоїв в Україні становить 5\%, але саме тут виробляють 47\% усіх відомих мінеральних вод в Україні. У виробництві мінеральних газованих вод у Карпатському регіоні провідні позиції займають Львівська та Закарпатська області $[5,17]$.

У Карпатському регіоні зосереджено більш $1 / 4$ всіх родовищ мінеральних вод в Україні, тут виділено основні області Львівська та Закарпатська, де зосереджено вуглекислі, азотно-метанові та метанові види мінеральних вод. Широко використовуються мінеральні води без специфічних компонентів і властивостей. Серед мінеральних вод специфічного складу можна виокремити йодобромні, борні, сірководневі, гідрокарбонатні вуглекислі, хлоридні мінеральні води.

Львівська область займає лідируючі позиції щодо ринку збуту, рівня урбанізації та інвестиційною привабливості з виробництва газованої мінеральної води, що обумовлено кількістю мінеральних джерел (понад 100), та станом на 01.01.2019 рік цей показник склав 21446,4 тис. дал.

На другому місці щодо вироблення мінеральної газованої води посідає Закарпатська область 14400 тис. дал, у зв'язку з наявністю великої кількості унікальних мінеральних джерел у даному регіоні [12].

На сьогодні, у Закарпатті налічується 382 виходи мінеральної води на поверхню. Далі за кількістю виробництва мінеральної води Полтавська область - 13574, 8 тис. дал., Івано-Франківська область 964,8 тис. дал., Запорізька область - 768 тис. дал., Рівненська область - 240 тис. дал. Регіон 3 най- меншою кількістю виробництва мінеральної води приходиться на Полтавську область.

Закарпатська область посідає перше місце серед областей регіону (від 4000 до $5000 \mathrm{~m}^{3} /$ добу), а Івано-Франківська та Чернівецька області мають найменші балансові експлуатаційні запаси мінеральних вод (від 500 до $1000 \mathrm{~m}^{3}$ /добу).

В цілому, сприятливі кліматичні умови, наявність великої кількості водних ресурсів, родовищ 3 мінеральною столовою та лікувально-столовою водою, історичні пам'ятки культури визничають роль України як важливого рекреаціи $\square$ ного регіону [15], успіху якого можна досягти через галузеву координацію, оновлення виробничо-збутовоі $\square$ бази, підвищення конкурентоспроможності продукціi $\square$.

Основними тенденціями, характерними для регіонального ринку є його локальність та наявність власних торговельних марок, які займають провідні позиції у регіонах.

Висновки та перспективи подальших розвідок. Систематизуючи вищевикладене, на основі моніторингу стану видобутку та тенденцій регіонального розвитку мінеральної води, оцінки бальнеологічних запасів у регіональному зрізі та виокремлення провідних торгових марок можна стверджувати, що кожний регіон має власні особливості, динаміку видобутку та розвитку мінеральних вод, обирає власну стратегію для нівелювання чинників, які негативно впливають на економічний розвиток регіону.

В цілому, характерною особливістю розвитку мінеральних вод $\epsilon$ високий рівень концентрації рекреаційних природно-географічних ресурсів, які широко використовуються в курортному господарстві та мають рекреаційні, оздоровчі, лікувальні властивості. Актуальність аналізу таких вод обумовлена можливістю розкриття перспектив розвитку туризму, рекреаційної діяльності, курортного господарства на рівні регіону, видобутку та розливу цілющих мінеральних вод.

3 точки зору регіональної диференціації виробничих потужностей видобутку мінеральної води в Україні можна виокремити чотири основні області: Закарпатська, Львівська, Полтавська та Івано-Франківська, де у відсотковому еквіваленті 
зосереджено виробничих потужностей більше половини від загального обсягу даної продукції [14].

Безумовно, водні споживчі ресурси є найважливішими природними ресурсами України [6], ефективне й стале споживання яких дозволяє забезпечити первинні потреби населення, підвищити експортний потенціал країни, сформувати позитивний імідж регіонального бренду та вийти на міжнародний рівень. Перспективами подальшого дослідження є застосування науково-методичного підходу щодо оцінки розвитку регіонального ринку мінеральної води із систематизацією ключових питань та аналізу конкурентоспроможності брендів.

\section{Література}

1. Ахромкін С. М. Проблеми використання водних ресурсів регіону // Ефективна економіка. 2010 . №12. URL: http://www.economy.nayka.com.ua/?op=1\&z=502 (дата звернення: 02.03.2020).

2. Верещака Т.В. Особливості розвитку ринку мінеральної води в Україні // Інформаційні технології: наука, техніка, технологія, освіта, здоров'я. 2017. Ч. IV. С.183

3. Малишева Н. Ю. Вплив поведінки споживачів на функціонування та розвиток ринку мінеральних вод України // Ефективна економіка. 2013. № 7. URL: http://nbuv.gov.ua/UJRN/efek_2013_7_49 (дата звернення: 02.03.2020).

4. Пахтер Ю.О. Мінеральні води як важлива складова розвитку курортно-рекреаційної сфери // Науковий вісник. 2009. Вип.28. С.45-48.

5. Стецюк О. карпатський регіон України в системі національного виробництва мінеральних вод // Вісник Львівського університету. Сер. географічна. 2014. Випуск 47. С. 254-264

6. Тюха I.В., Савчук I.В. Світові тенденції ринку безалкогольних напоїв // Еконоімка та держава. 2017. №12. C. 48-51.

7. Тур О. В. Ринок мінеральної води в Україні: виробництво та споживання // Економіка та держава. 2013. № 8. С. 105-111.

8. Химинець В.В. Місце та роль курортно-рекреаційного кластеру в сталому розвитку карпатського регіону // Науковий вісник Ужгородського університету. 2014. Вип.1(42). URL: http://www.visnyk-ekonold.uzhnu.edu.ua/images/pubs/42/42_49.pdf (дата звернення: 02.03.2020).

9. Національна доповідь про якість питної води та стан питного водопостачання в Україні у 2018 році. Міністерство регіонального розвитку будівництва. Київ: Науково-дослідний та конструкторсько-технологічний інститут міського господарства, 2019. 353 с.

10. Статистична інформація. Державна служба статистики: [Веб-сайт]. Київ, 2020. URL: http://www.ukrstat.gov.ua/ (дата звернення: 02.03.2020).

11. Kureda N., Yukhnovska Yu. Споживчі та економічні пропозиції бальнеологічних послуг на ринку лікувально-оздоровчого туризму каї карпатського регіону. URL: http://www.baltijapublishing.lv/download/econom-science/15.pdf (дата звернення: 02.03.2020).

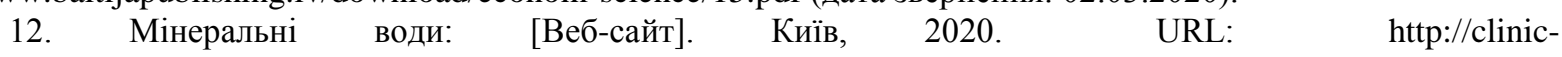
dovgogo.com/index.php/book/itemlist/category/278 (дата звернення: 02.03.2020).

13. Файвішенко Д. С. Світовий ринок мінеральної води // Агросвіт. 2019. №19. С.23-30.

14. Pro Consulting. Дослідження ринків: [Веб-сайт]. Київ, 2020. URL: https://proconsulting.ua/ua/issledovanie-rynka/analiz-rynka-mineralnyh-vod-ukrainy-2017-god (дата звернення: 02.03.2020).

15. Шаповалова I.О. Державне регулювання рінку мінеральної води.

URL:http://dspace.nbuv.gov.ua/bitstream/handle/123456789/24365/19-Shapovalova.pdf?sequence=1(дата звернення: 16.03.2020).

16. Мінеральні ресурси України - Карта вод підземних, лікувальної грязі та ропи: веб-сайт. URL: http://minerals-ua.info/mapviewer/voda.php (дата звернення: 16.03.2020).

Файвишенко Д.В. Доступно в мережі Internet 11.07.2020

кандидат экономических наук, доцент кафедра журналистики и рекламы

Киевский национальный торгово-экономический университет ул. Киото, 19, г. Киев, 02156

E-mail: fayvishenko.ds@gmail.com ORCID ID: 0000-0001-7880-9801

\section{ТЕНДЕНЦИИ РАЗВИТИЯ РЕГИОНАЛЬНЫХ РЫНКОВ МИНЕРАЛЬНОЙ ВОДЫ УКРАИНЫ}

Сегодня в условиях трансформации и динамичного развития новых сфер экономики, с учетом положительной макроэкономической динамики и социально-экологического воздействия фракторов 
(обострение экологической ситуации, усиление интереса к укреплению культурных традиций, изменение потребительских стереотипов), развитие рынка минеральной воды занимает ведущие позиции, где доминантной тенденцией является анализ развития региональных рынков.

В статье представлен анализ и мониторинг состояния добычи и тенденций развития регионального рынка минеральной воды, проведена оценка бальнеологических запасов в областях и выделены основные торговые марки минеральной воды в региональном разрезе. Сделан акцент на нивелирование факторов, негативно влияющие на экономическое развитие региона, продвижение и доступ к другим областям через сохранение и усиление региональных особенностей минеральной воды.

С точки зрения региональной дифференциации производственных мощностей добычи минеральной воды в Украине, можно выделить четыре основных области: Закарпатскую, Львовскую, Полтавскую и Ивано-Франковскую, где сосредоточены основные производственные мощности по добычи и реализации минеральной воды.

Актуальность анализа обусловлена возможностью раскрытия перспектив развития туризма, рекреационной деятельности, курортного хозяйства на уровне региона, добычи и розлива минеральных вод.

В целом, благоприятные климатические условия, наличие большого количества водных ресурсов, месторождений минеральной столовой и лечебно-столовой воды, памятников истории и культуры определяют роль Украины как важного рекреационного региона, успех которого может быть достигнут посредством координации секторов, обновления производственно-сбытовой базы, повышение конкурентоспособности продукции.

Ключевые слова: анализ ринка, бренд, региональный рынок, минеральная вода, торговая марка.

Fayvishenko D.

Ph.D, Associate Professor

Department of Journalism and Advertisement

Kyiv National University of Trade and Economics

str. Kyoto, 19, Kyiv, Ukraine, 02156

E-mail: fayvishenko.ds@gmail.com

ORCID ID: 0000-0001-7880-9801

\section{ANALYSIS OF DEVELOPMENT TRENDS OF REGIONAL MINERAL WATER MARKETS OF UKRAINE}

Nowadays, in the conditions of transformation and dynamic development of new sectors of the economy, taking into account positive macroeconomic dynamics and the socio-environmental impact of factors (exacerbating of the environmental situation, increasing interest in strengthening cultural traditions, changing consumer stereotypes), the development of the mineral water market takes a leading position where a dominant trend is an analysis of the development of regional markets.

The article presents the analysis and monitoring of the state of production and development trends of the regional mineral water market, assesses balneological reserves in the regions, and highlights the main brands of mineral water in a regional context. Emphasis was placed on leveling factors that negatively affect the economic development of the region, promotion and access to other areas through the preservation and strengthening of regional characteristics of mineral water. In terms of regional differentiation of mineral water production capacities in Ukraine, four main areas can be highlighted: Transcarpathian, Lviv, Poltava and Ivano-Frankivsk, where the main production capacities for the extraction and sale of mineral water are concentrated.

The relevance of the analysis is due to the possibility of revealing the prospects for the development of tourism, recreational activities, resort management at the regional level, the extraction and bottling of mineral waters.

In general, favorable climatic conditions, availability of a large amount of water resources, mineral table and medical-table water deposits, historical cultural monuments determine the role of Ukraine as an important recreational region, success of which can be achieved through sectoral coordination, updating of production and marketing base, increasing product competitiveness

Key words: market analysis, brand, regional market, mineral water, trademark. 


\section{References}

1. Akhromkin, Ye. M. (2010). Problemy vykorystannia vodnykh resursiv rehionu. Efektyvna ekonomika, (12). Retrieved March 02, 2020 from http://www.economy.nayka.com.ua/?op=1\&z=502

2. Vereshchaka, E. V. (2017). Osoblyvosti rozvytku rynku mineralnoi vody v Ukraini. Informatsiini tekhnolohii: nauka, tekhnika, tekhnolohiia, osvita, zdorov'ia, Ch. 4, 183.

3. Malysheva, N. Yu. (2013). Vplyv povedinky spozhyvachiv na funktsionuvannia ta rozvytok rynku mineralnykh vod Ukrainy. Efektyvna ekonomika, (7). Retrieved March 02, 2020 from http://nbuv.gov.ua/UJRN/efek_2013_7_49

4. Pakhter, Yu. O. (2009). Mineralni vody yak vazhlyva skladova rozvytku kurortno-rekreatsiinoi sfery. Naukovyi visnyk, (28), 45-48.

5. Stetsiuk, O. (20014). Karpatskyi rehion Ukrainy v systemi natsionalnoho vyrobnytstva mineralnykh vod. Visnyk Lvivskoho universytetu, (47), 254-264.

6. Tiukha, I. V., \& Savchuk, I. V. (2017). Svitovi tendentsii rynku bezalkoholnykh napoiv. Ekonoimka ta derzha$v a,(12), 48-51$.

7. Tur, O. V. (2013). Rynok mineralnoi vody v Ukraini: vyrobnytstvo ta spozhyvannia. Ekonomika ta derzhava, (8), 105-111.

8. Khymynets, V. V. (2014). Mistse ta rol kurortno-rekreatsiinoho klasteru v stalomu rozvytku karpatskoho rehionu. Naukovyi visnyk Uzhhorodskoho universytetu, (1(42)), 241-247. Retrieved March 02, 2020 from http://www.visnykekon-old.uzhnu.edu.ua/images/pubs/42/42_49.pdf

9. Natsionalna dopovid pro yakist pytnoi vody ta stan pytnoho vodopostachannia v Ukraini u 2018 rotsi. (2019). Naukovo-doslidnyi ta konstruktorsko-tekhnolohichnyi instytut miskoho hospodarstva, 1-353.

10. Derzhavna sluzhba statystyky Ukrainy. Retrieved March 02, 2020, from http://www.ukrstat.gov.ua/

11. Kureda, N., \& Yukhnovska, Yu. Spozhyvchi ta ekonomichni propozytsii balneolohichnykh posluh na rynku likuvalno-ozdorovchoho turyzmu krain karpatskoho rehionu. Retrieved March 02, 2020, from http://www.baltijapublishing.lv/download/econom-science/15.pdf
12. Mineralni
vody.
(2020).
Retrieved
March
02,
2020
from
http://clinic-

dovgogo.com/index.php/book/itemlist/category/278

13. Faivishenko, D. S. (2019). Svitovyi rynok mineralnoi vody. Ahrosvit, (19), 23-30.

14. Analiz rynku mineralnykh vod Ukrainy. 2017 rik. (2020). Pro Consulting. Doslidzhennia rynkiv. Retrieved March 02, 2020, from https://pro-consulting.ua/ua/issledovanie-rynka/analiz-rynka-mineralnyh-vod-ukrainy-2017-god

15. Shapovalova, I. O. Derzhavne rehuliuvannia rinku mineralnoi vody. Retrieved March 16, 2020, from http://dspace.nbuv.gov.ua/bitstream/handle/123456789/24365/19-Shapovalova.pdf?sequence=1

16. Mineralni resursy Ukrainy - Karta vod pidzemnykh, likuvalnoi hriazi ta ropy. Retrieved March 16, 2020, from http://minerals-ua.info/mapviewer/voda.php

Received 27 March 2020

Approved 10 April 2020

Available in Internet 11.07.2020

Цитування згідно ДСТУ 8302:2015

Файвішенко Д.С. Аналіз тенденцій розвитку регіональних ринків мінеральної води України. 2020. Т.12, вип. 2. С. 22-29. doi: 10.15673/fie.v12i2.1736

Cite as APA style citation

Fayvishenko, D. (2020). Analysis of development trends of regional mineral water markets of Ukraine. Food Industry Economics, 12(2), 22-29. doi: 10.15673/fie.v12i2.1736 